\title{
U-series dating and isotope geochemical study of the Gellért Hill (Budapest) travertine
}

\section{Sándor Kele*}

Institute for Geochemical Research

Hungarian Academy of Sciences, Budapest

\author{
Attila Demény \\ Institute for Geochemical Research \\ Hungarian Academy of Sciences, Budapest
}

\author{
Gyula Scheuer \\ Budapest
}

\author{
Chuan-Cou Shen, Hong-Wei Chiang \\ Department of Geosciences \\ National Taiwan University, Taipei
}

\begin{abstract}
Travertine is quite a common formation in the area of Budapest (Hungary) indicating strong hydrothermal activity during the Pliocene and Quaternary. It covers former terraces of the Danube River and older geomorphologic horizons; thus, it is an important archive to date fluvial terraces and tectonic movements. Despite numerous investigations performed on these deposits, only few radiometric data are available so far and the absence of the exact timing information hindered paleoclimatic interpretation. The area of Gellért Hill consists mainly of Upper Triassic dolomite, but Quaternary travertine can also be found. In this study a detailed petrographic and stable isotope geochemical study of four travertine sites (1. Ifjúsági Park; 2. Számadó u. (Street); 3. Kelenhegyi u. (Street); 4. Somlói u. (Street)) of the Gellért Hill area is presented, along with analyses on the recent carbonate deposits of Gellért Hill and Sárosfürdő. The travertine of Ifjúsági Park and Számadó u. are spring cone deposits, while the travertine of the Kelenhegyi u. represents a shallow-water depositional environment. Based on the paleontological studies of Jánossy (in Scheuer and Schweitzer, 1988) the Gellért Hill travertine was thought to have been formed during the Lower Pleistocene; however, no radiometric age dating had been performed on these deposits prior our study. Our U/Th analyses yielded ages of $250 \pm 44 \mathrm{ky}$ for the Ifjúsági Park travertine (220 $\mathrm{m}$ asl) and $180 \pm 49 \mathrm{ky}$ for the Számadó u. travertine (195 m asl). These new U/Th ages are in contradiction with the previously assumed Lower Pleistocene age, implying gradual relative decrease in the paleokarst water-level and proving that the elevation of the individual travertine deposits not necessarily show their relative age. The uplift rates of Gellért Hill calculated from the U/Th age data and elevation of travertine occurrences range between 0.47 and $0.52 \mathrm{~mm} / \mathrm{yr}$, which is significantly higher than the uplift rates calculated for the Rózsadomb area $(0.200 .25 \mathrm{~mm} / \mathrm{yr}$; Kele et al., submitted). The difference in the incision rates between the individual sub-areas suggests that selective uplift was characteristic
\end{abstract}

Addresses: S. Kele, A. Demény: H-1112 Budapest, Budaörsi u. 45, Hungary

Gy. Scheuer: H-1126 Budapest, Szendrő u. 6, Hungary

S. Chuan-Cou, C. Hong-Wei: No. 1, Sec. 4, Roosevelt Road, Taipei, Taiwan 106

Received: September 3, 2010; accepted: October 28, 2010

*Corresponding author: E-mail: keles@geochem.hu 
for the Buda Hills during the Middle Pleistocene; thus, up-scaling reconstruction of paleokarst waterlevel for the whole area from a given locality is not possible.

Oxygen isotope analyses of recent carbonate deposits of Gellért Hill, Sárosfürdő and Rudas Spa revealed that these calcites precipitated under non-equilibrium conditions, and the measured calcitewater oxygen isotope fractionation show the same positive shift relative to "equilibrium values" as was observed in the case of the recently-forming Egerszalók travertine (Kele et al. 2008). Assuming that the water of the paleo-springs of Gellert Hill derived from precipitation infiltrated during interstadial periods of the Pleistocene and considering non-equilibrium deposition (i.e. using the empirical calcite-water oxygen isotope fractionation of Kele et al. 2008), their calculated paleotemperature could range between $22( \pm 4){ }^{\circ} \mathrm{C}$ and $49( \pm 6){ }^{\circ} \mathrm{C}$. Based on the $\delta^{18} \mathrm{O}_{\text {travertine }}$ differences the Ifjúsági Park and the Számadó u. spring cone type travertine was deposited from the highest temperature water, while from the lowest temperature water the travertine of Kelenhegyi $\mathrm{u}$. was formed.

Key words: travertine, Gellért Hill, uranium-series dating, Middle Pleistocene, stable isotopes, uplift

\section{Introduction}

Travertine and freshwater tufa deposits formed in lakes and rivers are one of the most important continental climate-related deposits. They have been widely studied since the end of the 19th century (Weed 1889), but their potential to provide a high-resolution terrestrial paleoclimate record was discovered only in recent decades (e.g. Hennig et al. 1983; Ford and Pedley 1996; Pentecost 1995).

Travertine is a frequent deposit in Hungary and is widespread in the area of Budapest (Buda Hills) as well, indicating strong hydrothermal activity during the Pliocene and Quaternary. Since it covers the former terraces of the Danube River and older geomorphologic horizons, it is an important archive for dating fluvial terraces and tectonic movements. The study of Hungarian travertine goes back to the beginning of the 20th century. After the first field observations of Kormos and Schréter (1916), Horusitzky (1939) and Schréter (1953), sedimentological and morphological investigations on travertine became popular research subjects in the 1970s (e.g. Scheuer and Schweitzer 1988). The travertine deposits of the Gerecse and Buda Hills were correlated with the terrace levels of the Danube River and its tributaries by Pécsi (1959) and Kretzoi and Pécsi (1982) based mainly on geomorphological, sedimentological and biostratigraphic considerations. Although further detailed studies have been conducted (e.g. Bakacsi 1993; Kele et al. 2003; Korpás et al. 2004), geochemical and stable isotope geochemical analyses of travertine were rather scarce in Hungary until the early 2000s (Rózsavölgyi 1964; Mihályi-Lányi 1964; Opauszky et al. 1964; Szöőr et al. 1992). In the last years Földvári et al. (2003), Kele et al. (2003), Korpás et al. (2004), Kele et al. (2006), Veres (2007), Kele et al. (2008), Sierralta et al. (2010), Kele (2009) and Kele et al. (submitted) published stable isotope results from Hungarian travertine sites. Despite numerous research project performed on these deposits, radiometric age data from Hungarian travertine deposits have rarely been reported (e.g. Pécsi 1973; Schwarcz 1980; Schwarcz and Skoflek 1982; Kretzoi and Pécsi 1982; Hennig et al. 1983; Schwarcz and Latham 1984), although they are essential for exact 
paleohydrological, paleoclimatological and tectonic conclusions. Leél-ôssy et al. (2009) determined $195 \mathrm{ky}$ ( $+11 \mathrm{ky},-10 \mathrm{ky}$ ) ages on cave raft calcites collected from the Citadella Crystal Cave located at $167 \mathrm{~m}$ (asl) in Gellért Hill, but no radiometric age dating analyses have been performed so far on the travertine of the study area.

On Gellért Hill four travertine sites (1. Ifjúsági Park; 2. Számadó u.; 3. Kelenhegyi u. 4. Somlói u.) were described by Schréter (1953) and Scheuer and Schweitzer (1988) (Fig. 1). The primary goal of this study is to provide the first radiometric age data from these deposits in order to calculate the uplift rate of Gellért Hill. Additionally, sedimentological and stable isotope analyses were performed in order to reconstruct depositional environments of the Gellért Hill travertine deposits and to estimate the temperature of their parent thermal springs.

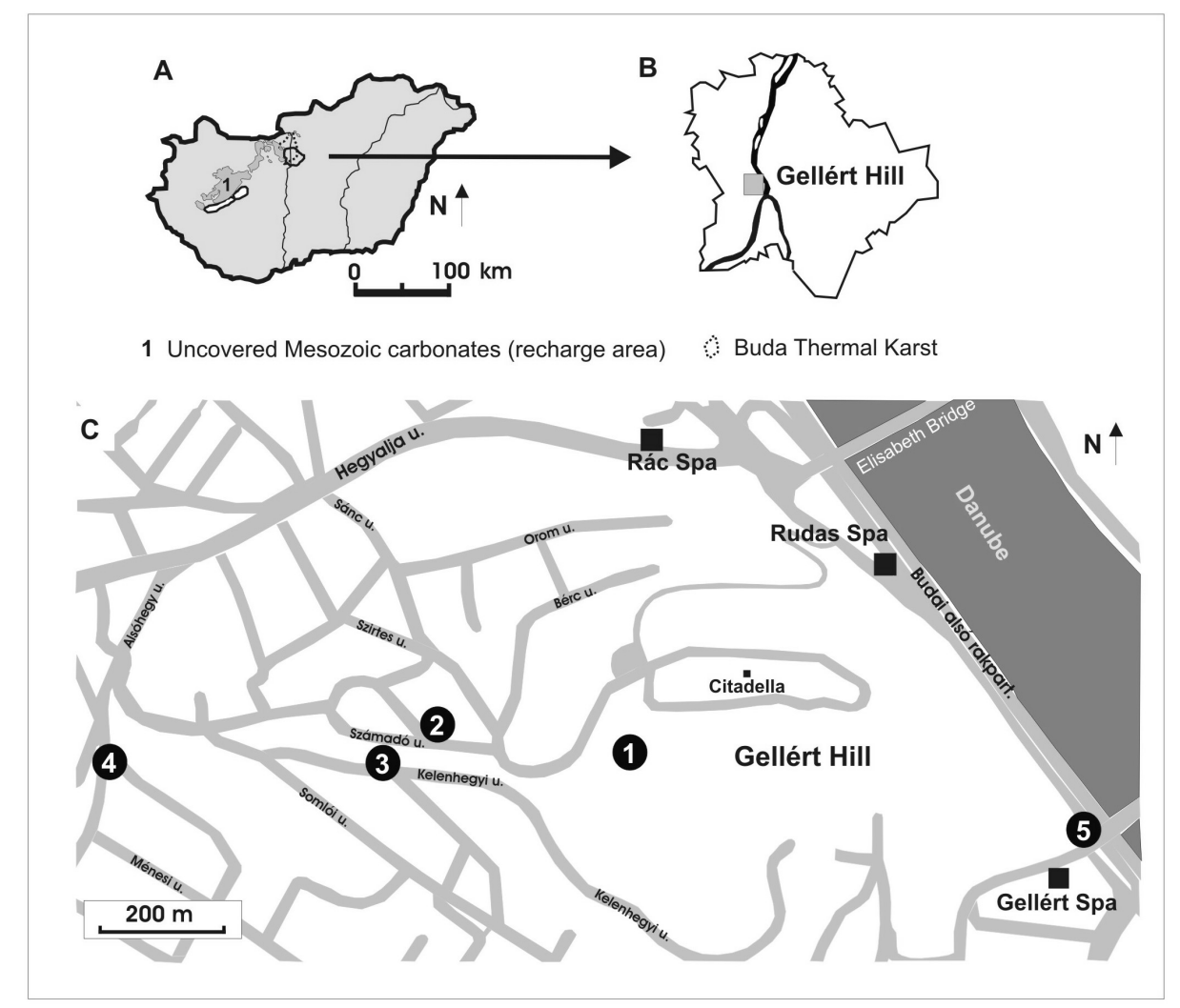

Fig. 1

A) Map of Hungary, indicating the location of the Buda Thermal Karst and its recharge area in the Transdanubian Central Range (modified after Erôss et al. 2006). B) Schematic map of Budapest showing the location of the studied Gellért Hill are. C) Travertine occurrences on Gellért Hill (the map is a modified version from Google and Tele Atlas). The locations of the travertine occurrences are shown after Kele (2009). Travertine occurrences: Ifjúsági Park (1), Számadó u. (2), Kelenhegyi u. (3), Somlói u. (4), Sárosfürdő (5) 


\section{Geologic, structural and hydrogeologic background}

The geologic buildup of Gellért Hill was presented in detail by Korpás et al. (2002) (Figs 2 and 3). The main part of Gellért Hill consists of Upper Triassic dolomite containing organic-rich marl and clay-marl intercalations. A thin cherty limestone is intercalated with or covers the dolomite. The Upper Eocene begins with conglomerate (9-25 m in thickness), breccia and sandstone deposits. The content of the marl matrix increases upward, up to the Buda Marl. Sandstone and nummulitic limestone (Szépvölgyi Limestone) intercalations prevail in the upper part of the section. The bryozoic Buda Marl is covered by shallow bathyal clay (Oligocene Tard Clay and Kiscell Clay) and then by the Upper Oligocene Törökbálint Sandstone, which is known only from drilling cores in the area. The Quaternary is represented by travertine, loess, slope deposits and fluvial gravel and sand.

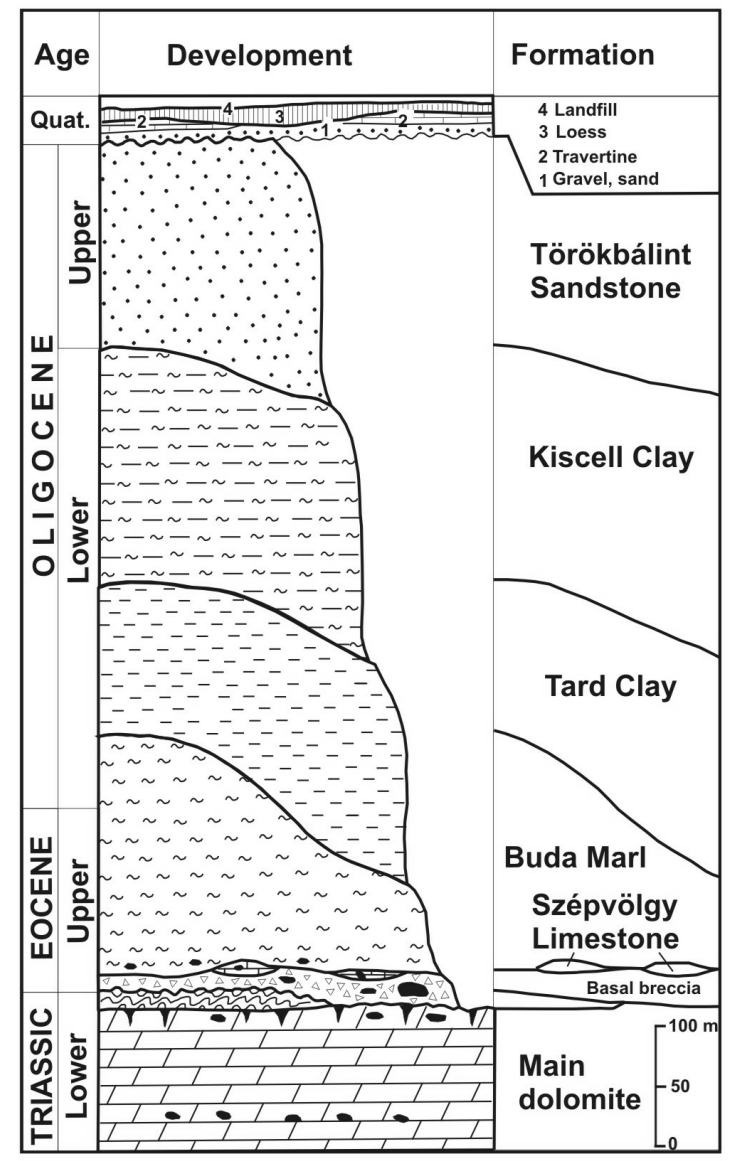

- Paleokarst level with cavities Tr Neptunian dyke
Fig. 2

Lithostratigraphic column of the Gellért Hill area (modified after Korpás et al. 2002) 


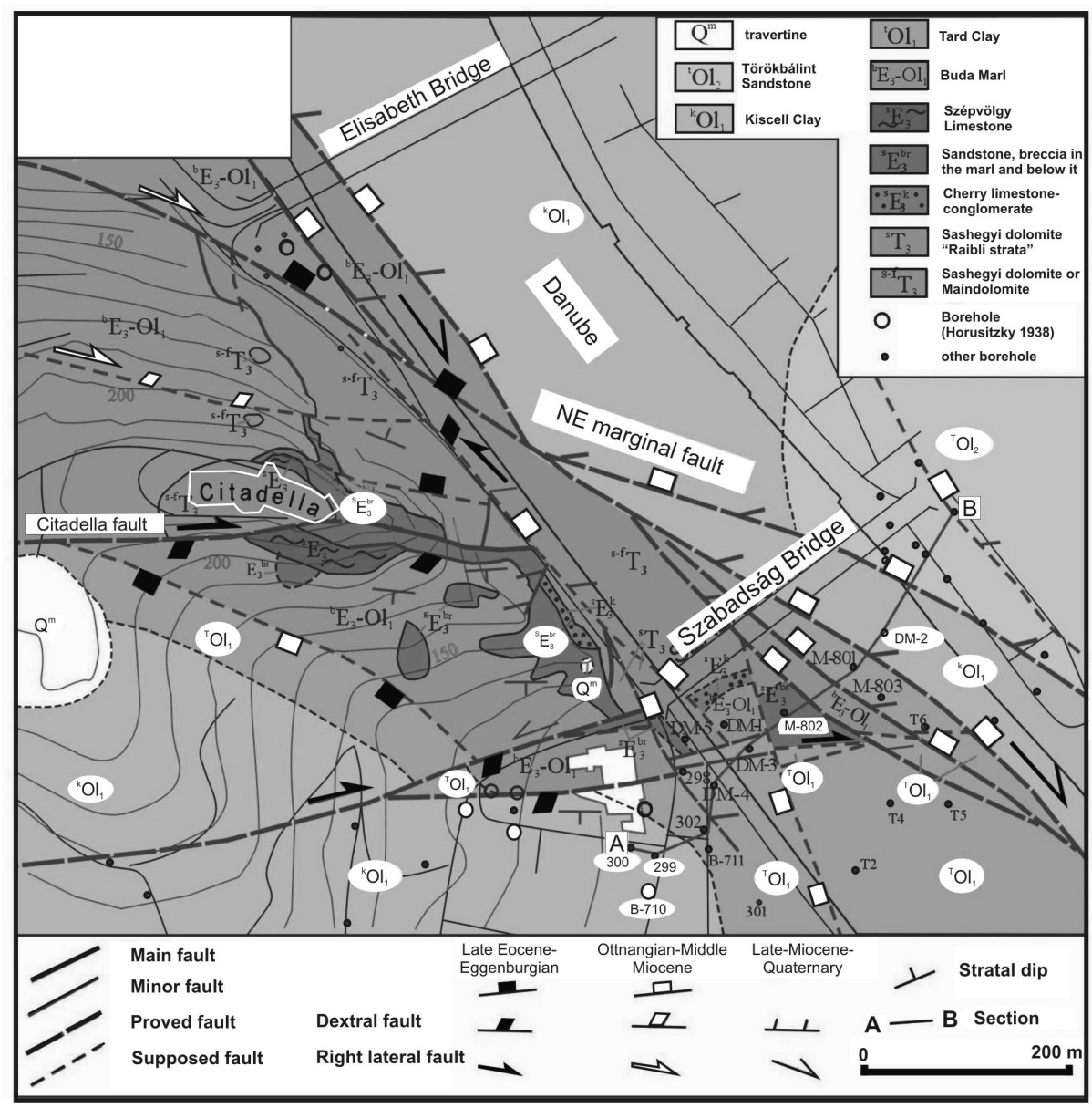

Fig. 3

Geologic map of the Gellért Hill area (modified after Fodor, 2001 in Korpás et al. 2002)

Gellért Hill is bordered by tectonic lines and the area is strongly influenced by structural movements (Wein 1977; Korpás et al. 2002). Three Tertiary stress fields affected the area, but a Triassic event is also possible according to Korpás et al. (2002). The Tertiary stress fields characterize four deformational events. The oldest, NNE-SSW tension created the E-W trending "Citadella Fault". Due to its dextral normal synsedimentary motion, the southeastern part of the hill subsided ca. $100 \mathrm{~m}$ (Korpás et al. 2002). The fault deformed the only partly consolidated sediments and induced creep, sliding, and replacement deposition of the Upper Eocene-lowermost Oligocene clastics. Faulting includes steeply dipping sedimentary dikes with sandy marl and limestone fillings. Most of dikes and the 
marl itself were silicified due to thermal fluids circulating along the main fault (Korpás et al. 2002). After the Early Oligocene the western segment of the "Citadella Fault" was reactivated and connected to another dextral normal fault south of Gellért Hill. The Ottnangian-Middle Miocene phase created large normal slip on the northeastern boundary fault of Gellért Hill. The fault is situated below the rock cliff at the Elisabeth Bridge and crosses the Danube, branching into several fault strands. This fault represents the eastern boundary fault of the entire Buda Hills and might have accumulated up to $1000 \mathrm{~m}$ of separation. The fault was reactivated during the late Miocene-Quaternary, due to ESE-WNW tension.

To correctly evaluate the results of the analyses performed on the travertine (which is the best evidence of paleo-spring activity), it is necessary to obtain an overview the hydrogeology of the investigated area. Many authors have already studied the thermal springs of Budapest and its hydrogeology (e.g. Schréter 1919; Schafarzik 1921; Víg and Horusitzky 1940; Papp 1962; Scheuer 1964; Vendel and Kisházy 1964; Alföldi et al. 1968; Kovács and Müller 1980; Erőss et al. 2008), while stable isotope studies on the thermal waters have been performed by Deák (1978), Babidorics et al. (1998) and Fórizs et al. (2007). The history of development of the paleo-thermal springs of Budapest were outlined by Scheuer and Schweitzer $(1980 a, b)$. In the latest years radon and radium measurements were performed by Palotai et al. (2005) and Fekete (2006).

Gellért Hill belongs to the Buda Thermal Karst containing thermal springs with elevated temperatures $\left(35-43^{\circ} \mathrm{C}\right)$, which are connected to the NW-SE normal fault zone of the area (Korpás et al. 2002). The main aquifers of the Buda Thermal Karst are both Mesozoic carbonates and Eocene limestone. The Buda Thermal Karst is in subsurface connection with the groundwater system of the Transdanubian Central Range $200 \mathrm{~km}$ away from the Buda Hills in a W-SW direction. The several thousand meter-thick Mesozoic carbonate sequence of the Transdanubian Central Range serves as an aquifer and karstic recharge area for the Buda Thermal Karst. The cold water infiltrated in the Transdanubian Central Range is heated up by thermal convection during its long regional-scale flow and discharge to the surface as thermal water on the right (western) side of the Danube, and in the riverbed along the step-faulted boundary of the uplifted hills and the subsided basin to the east (Kovács and Müller 1980; Fig. 4). At the eastern margin of the Buda Hills many medium and high temperature thermal springs discharge close to the current level of the Danube River (e.g. Békásmegyer, Attila Spring, Óbuda, Árpád Spring, Pünkösdfürdő, Lukács-Császár Spa, etc.). Some of these springs discharge water directly from the lowest karstic blocks (e.g. springs of the Gellért and Rudas Spas), while others reach the surface breaking through permeable deposits (Római Spa and Attila Spring at Békásmegyer) (Scheuer and Schweitzer 1989). Recent carbonate precipitations can be easily found at these springs and thermal wells (e.g. Béke well, Dagály; Zsigmondi-5 well, Margitsziget). 
Fig. 4

Schematic cross-section and model of the Buda Thermal Karst system (modified after Kovács and Müller 1980)

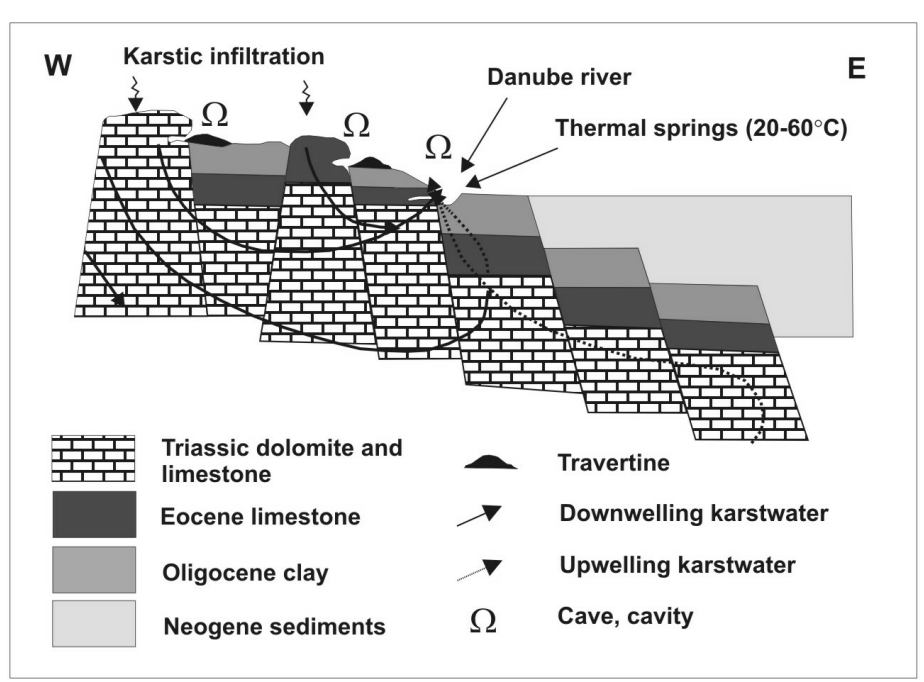

The springs discharging at Gellért Hill are characterized by uniform chemical composition and temperature (Erőss et al. 2008) and their discharge is indirectly influenced by the Danube River, which represents the base level of erosion. Based on ${ }^{14} \mathrm{C}$ measurements of Deák (1978) the age of these waters is 5000 to 16000 years. Babidorics et al. (1998) presented $\delta^{18} \mathrm{O}_{\text {water }}$ values around $-11.6 \%$ (VSMOW) from the Gellért Tunnel, suggesting that the water infiltrated in the Ice Age (i.e. more than $10 \mathrm{ky}$ ago). All of the springs of Gellért Hill (e.g. Mátyás Spring, Juventus Spring, Gül Baba Spring, Ôsforrás Spring, etc.) discharge from Triassic dolomite and they supply the Rác, Rudas, and Gellért Spas (Alföldi et al. 1968). Traces of paleo-thermal spring activity are well visible as travertine deposits, spring caves and cavities on and around Gellért Hill. Active thermal springs fed the Rác, Rudas and Gellért Spas, while some of them discharge at the bottom of the Danube River. Carbonate precipitations are observable on the surface of the hot $\left(40^{\circ} \mathrm{C}\right)$ water of the Gellért Tunnel and at the Gül-baba Spring (Fig. 5E, F). The most spectacular recently forming carbonate of the Gellért Hill area is the "travertine beard" in the Rudas Spa (Fig. 6), which was studied in detail by Veres (2007). Holocene travertine can also be found below the building of the Rudas Spa, which can be considered as the deposit of the Hungária, Udvari, or the Kossuth Springs (Papp 1942) and around the Rác Spa (Hajnal et al. 2005). The temperatures of the Gellért Hill springs are generally higher than $40^{\circ} \mathrm{C}$ and their temperature and discharge rate is in close relationship with the water level of the Danube River. 


\section{Materials and methods}

Altogether four travertine occurrences (two of them [Ifjúsági Park, Számadó u.] are autochthonous and two allochthonous [Somlói u., Kelenhegyi u.]) were sampled in the area of Gellért Hill (Fig. 1). During field trips, beside sampling and

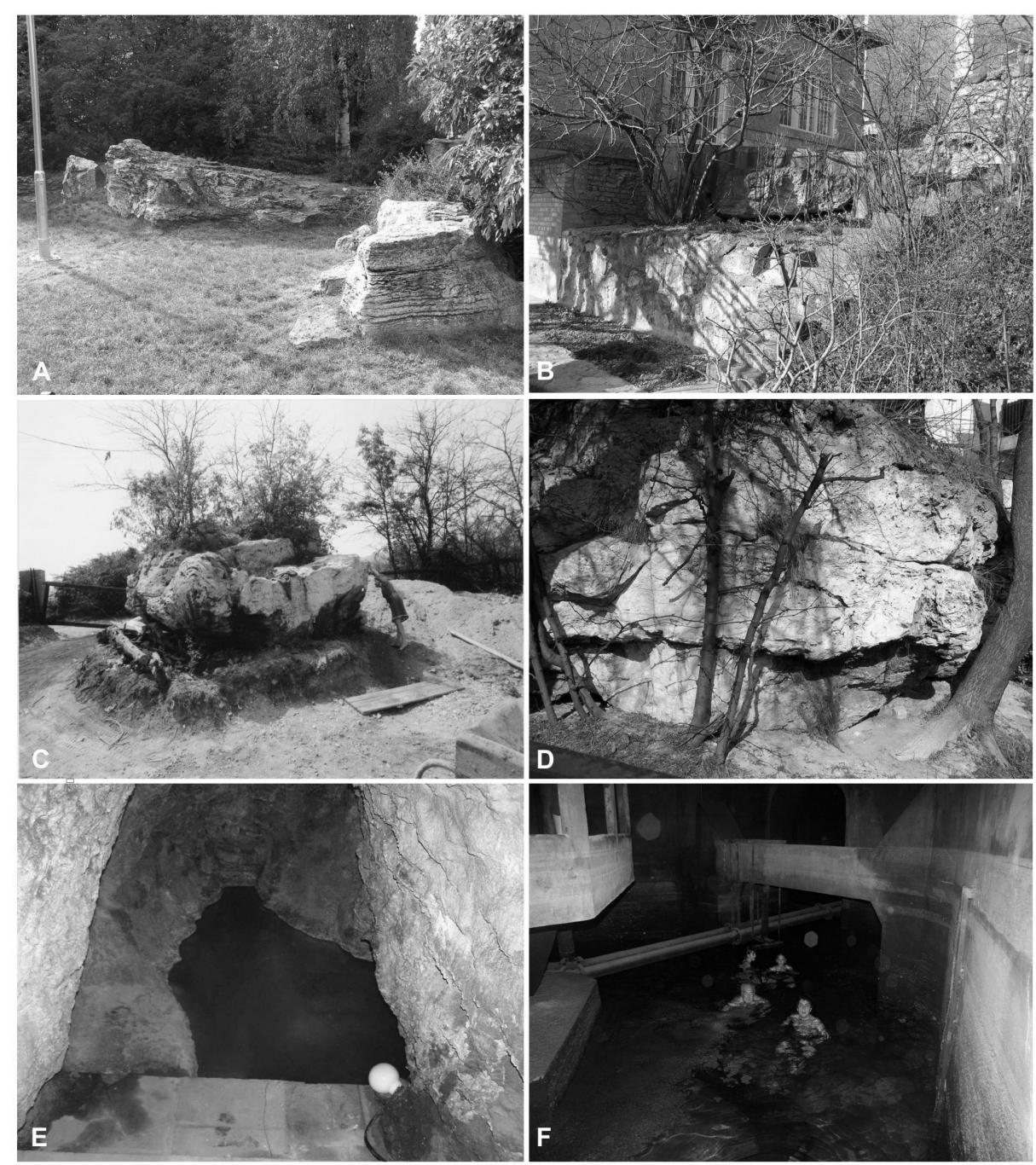

Fig. 5

Pictures of the most important travertine occurrences of the Gellért Hill area: A) Remnant of a spring cone in Ifjúsági Park; B) Travertine located along Kelenhegyi u. 76; C) and D) Travertine block in the garden of Számadó u. 7; E) Recent carbonate precipitations in the Gül Baba spring cavity located at the foot of Gellért Hill, close to the Danube River; F) Ösforrás. The surface of the water is covered by a thin calcite layer. In the water Szabolcs Leél-Össy on the left and Sándor Kele on the right; The C photo was taken by Gyula Scheuer in the 70s, while the F photo was taken by Mehmet Oruç Baykara 
sedimentological observations, the geographic position and elevation of the occurrences were also determined using a GPS device. Detailed petrographic analyses were conducted on the main lithofacies types of each occurrence using polished thin sections and optical microscope to infer the depositional environment. For the microfacies description the terminology of Folk (1959) and Dunham (1962) were used.

Stable carbon and oxygen isotope measurements were performed on 15 travertine samples using Finnigan delta $S$ and delta Plus XP mass spectrometers at the Institute for Geochemical Research, Hungarian Academy of Sciences, Budapest, Hungary. Carbon and oxygen isotope analyses of bulk carbonate samples were carried out using both the conventional phosphoric acid method $\left(\mathrm{H}_{3} \mathrm{PO}_{4}\right.$ digestion method at $\left.25^{\circ} \mathrm{C}\right)$ of McCrea (1950) and the continuous flow technique (Spötl and Vennemann 2003). Standardization was conducted using laboratory calcite standards calibrated against the NBS 18 and NBS 19 standards. All samples were measured at least in duplicate and the mean values are given in the standard delta notation in permill $(\% \circ)$ relative to V-PDB $\left(\delta^{13} \mathrm{C}\right)$ and V-SMOW $\left(\delta^{18} \mathrm{O}\right)$ following the equation $\delta=\left(\mathrm{R}_{\text {sample }} / \mathrm{R}_{\text {standard }}-1\right) \times 1000$, where $R_{\text {sample }}$ and $R_{\text {standard }}$ are the ${ }^{13} \mathrm{C} / 12 \mathrm{C}$ and $18 \mathrm{O} / 16 \mathrm{O}$ ratios in sample and standard, respectively. Reproducibilities are better than $\pm 0.1 \%$ or $\delta^{13} \mathrm{C}$ and $\delta^{18} \mathrm{O}$ values of carbonates.

U/Th dating was completed in the High-precision Mass Spectrometry and Environment Change Laboratory (HISPEC), Department of Geosciences, National Taiwan University (Taipei, Taiwan). Three samples from two travertine sites collected from the area of Gellért Hill were analyzed using a Thermo Electron Neptune Multi-Collector - Inductively Coupled Plasma Mass Spectrometer (MC-ICPMS) (Shen et al. 2002, 2006, 2008). The technique is based on the precipitation of uranium at the moment of deposition of carbonates in the absence of thorium. After carbonate deposition, due to the radioactive decay of ${ }^{234} \mathrm{U}$ the ${ }^{230} \mathrm{Th}$ concentration starts increasing in the carbonate; hence the ${ }^{230} \mathrm{Th} /{ }^{234} \mathrm{U}$ ratio of the travertine depends on its age (Edwards et al. 1987; Richards and Dorale 2003). Before high-precision U/Th analyses, the samples were prepared (crushed, weighed and cleaned using ultrasonic cleaning methods) in ultra-clean laboratory conditions ("class-10 000" geochemical cleanroom) using a "class-100 laminar-flow clean working bench". U-Th chemistry was performed in the Geochemistry Technology Laboratory of the Department of Geosciences, National Taiwan University (NTU). Travertine sub-samples (0.1-0.3 g) were prepared with chemical methods described by Edwards et al. (1988) and Shen et al. (2003) for U-Th chemistry.

Samples were spiked with a ${ }^{229} \mathrm{Th}-{ }^{233} \mathrm{U} \_{ }^{236} \mathrm{U}$ triple-spike isotope dilution method to correct mass bias and determine uranium concentration (Shen et al. 2002). A protocol, using one newly-developed MasCom secondary electron multiplier (SEM) with repelling potential quadrupole (RPQ), was employed. Only $1-4 \mathrm{ng}$ of $U$ is required to reach the 2 -sigma reproducibility of $1-2 \%$. The 
absence of significant difference between measurements of standards and carbonate samples on ICP-sector-field-MS (Shen et al. 2002), and on MC-ICP-MS, certify the developed MC-ICP-MS methodology. Uranium and thorium were separated by $\mathrm{Fe}$ co-precipitation and anion-exchange chromatography. The uranium and thorium aliquots were dissolved in $1 \% \mathrm{HNO}_{3}+0.005 \mathrm{~N} \mathrm{HF}$ for instrumental measurements (Shen et al. 2002). The obtained ages are absolute ages given as years before present.

For U/Th measurements clean, dense and white-colored massive travertine samples were chosen to avoid contamination with clay-minerals which would provide additional ${ }^{232} \mathrm{Th}$ pollution. However, since the travertine samples are surficial carbonate deposits, they contained high amount of detrital Th, which lowered the accuracy of the measurements. Thus, age corrections were applied, because even a small amount of U-derived Th may have an effect on the U/Th age of the samples. The average accuracy was $\pm 47 \mathrm{ky}$ (Table 1 ).

Table 1

Stable carbon- and oxygen isotopic composition, approximate radiometric age, elevation above sea level and GPS coordinates of travertine occurrences of Gellért Hill

\begin{tabular}{|c|c|c|c|c|c|c|}
\hline \multirow[b]{2}{*}{ Name } & $\delta^{18} \mathrm{O}_{\text {average }}$ & $\delta^{18} \mathrm{O}_{\text {average }}$ & $\delta^{13} \mathrm{C}_{\text {average }}$ & Age & $h$ (asl) & \multirow[b]{2}{*}{ GPS coordinate } \\
\hline & $\begin{array}{l}\text { [\%, V- } \\
\text { PDB] }\end{array}$ & {$[\%, \mathrm{~V}-\mathrm{SMOW}]$} & {$[\%, \mathrm{~V}-\mathrm{PDB}]$} & ky & $\mathrm{m}$ & \\
\hline $\begin{array}{l}\text { Gellért Hill, } \\
\text { Ifjúsági park }\end{array}$ & -12.9 & 17.6 & 1.9 & $250000 \pm 43$ & 220 & $\mathrm{~N} 47^{\circ} 29155^{\prime}$ EO $19^{\circ} 02606^{\prime}$ \\
\hline $\begin{array}{l}\text { Gellért Hill, } \\
\text { Számadó u. }\end{array}$ & -10.7 & 19.9 & 0.5 & $180000 \pm 49$ & 195 & N $47^{\circ} 29182^{\prime}$ EO $19^{\circ} 02302^{\prime}$ \\
\hline & & & & $160000 \pm 50$ & & \\
\hline $\begin{array}{l}\text { Gellért Hill, } \\
\text { Kelenhegyi u. }\end{array}$ & -9.9 & 20.7 & -2.9 & & 175 & N 47 $49148^{\prime}$ EO $19^{\circ} 02220^{\prime}$ \\
\hline $\begin{array}{l}\text { Gellért Hill, } \\
\text { Somlói u. }\end{array}$ & -11.3 & 19.3 & -0.5 & & 150 & $\mathrm{~N} 47^{\circ} 29$ 177' EO $19^{\circ} 01892^{\prime}$ \\
\hline $\begin{array}{l}\text { Gellért Hill, } \\
\text { Ősforrás }\end{array}$ & -14.9 & 15.6 & 1.2 & recens & $104^{*}$ & N $47^{\circ} 2904.99^{\prime}$ EO $19^{\circ} 0309.99^{\prime}$ \\
\hline Rudas Spa* & -15.1 & 15.3 & 1.4 & recens & $122^{*}$ & N 47 $2920.30^{\prime}$ EO $19^{\circ} 0252.19^{\prime}$ \\
\hline
\end{tabular}

*based on Veres 2007

\section{Results}

\section{Sedimentology and microfacies description}

The Pleistocene travertine deposits of the Buda Hills were formed in diverse depositional environments (e.g. lake, valley-side, spring cone deposits) (Scheuer and Schweitzer 1988; Kele 2009); thus, their morphology is quite variable. In this study four travertine sites were investigated from Gellért Hill: (i) a remnant of a spring cone (or fissure ridge) on the top of Gellért Hill, Ifjúsági Park (220-215 m asl (Fig. 5A); (ii) 4-5 m high spring cone at Számadó u. 7 (195 m asl, Fig. 5C and D) and the detrital travertine of (iii) Kelenhegyi u. 75. (170 m asl, Fig. 5B) and (iv) Somlói u. (150 m asl). In general, the travertine of Gellért Hill is a grayish-white, dense, hard and sometimes laminated carbonate rock. 
Fig. $6 \rightarrow$

Picture of the still depositing "travertine beard" in the Rudas Spa (the photo was taken in 2005; Veres 2007)

Fig. $7 \downarrow$

Macroscopic photos of the characteristic travertine samples collected from the Gellért Hill area: A) Layered travertine from the fossil spring cone (fissure ridge?) located in Ifjúsági Park. B) Homogeneous travertine sample from the fossil spring cone of Számadó u. 7. C) Photograph of a phytohermal travertine sample collected close to Kelenhegyi u. D) Massive, pore-free travertine (calcarenite) located close to Somlói u.
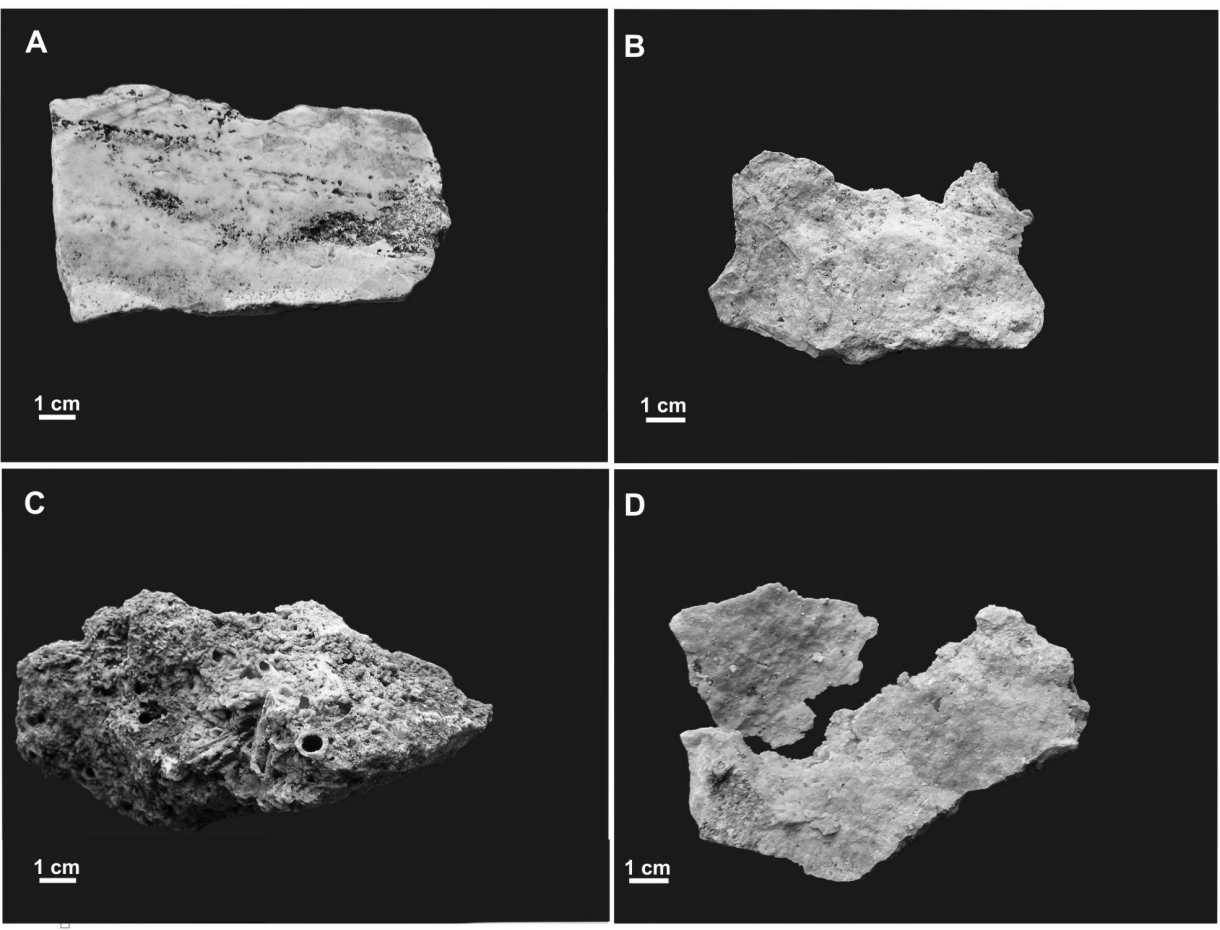

Central European Geology 52, 2009 
The Pleistocene travertine of the Ifjúsági Park is well-layered, grayish-white in color, has pelmicritic texture and it is free of flora and fauna (Fig. 7A, Fig. 8A). The samples collected from the $4-5 \mathrm{~m}$ high and $5 \mathrm{~m}$ wide fossil spring cone of Számadó u. 7 are hard, finely layered (sometimes homogeneous), they have pelmicritic texture and contain oncoids (Fig. 8B) and plant remnants as well. The autochthonous travertine of the Kelenhegyi u. 76 (Fig. 5B) is located in a private area; thus, it was not accessible. The travertine debris along the street contains remnants of plants forming phytohermal structure (e.g. Fig. 7C) and it has micritic-microsparitic texture (Fig. 8C). There is only one massive, allochthonous travertine block close to the Somlói $u$. which has pelmicrosparitic texture and it contains remnants of shells of ostracods, but peloids dominate in the texture (Fig. 7D, Fig. 8D).
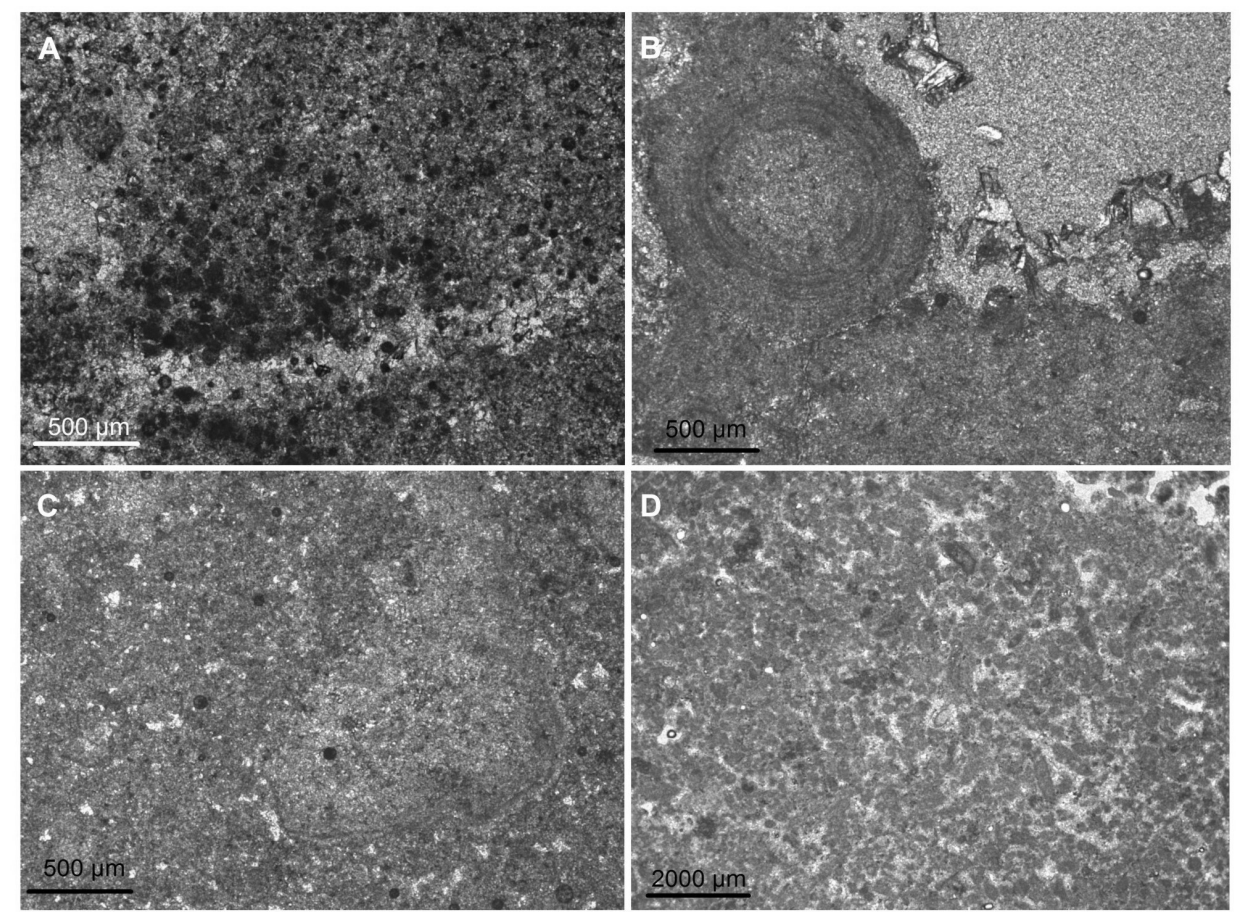

Fig. 8

Microphotographs of typical microfacies and micromorphological features of the travertine collected from the Gellért Hill area: A) Flora and fauna-free pelmicritic texture from the Ifjúsági Park travertine; B) Oncoid in the pelmicritic texture of the Számadó u. travertine; C) Micritic-microsparitic texture from the allochthonous Kelenhegyi $u$. travertine and pelmicrosparitic texture from the allochthonous travertine block of Somlói u. (D). In the latter example remnants of shells can also occur 
Results of $U /$ Th dating measurements

Table 1 contains the approximate age data, together with the precision of the measurements. The data prove that the travertine of Gellért Hill was formed during the Middle Pleistocene, about 160-250 ky ago. The travertine of Ifjúsági Park $(220 \mathrm{~m}$ asl) yielded an age of $250 \pm 44 \mathrm{ky}$, while the travertine block of

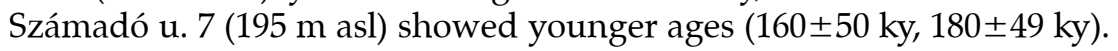

\section{Stable $\mathrm{C}$ and $\mathrm{O}$ isotope compositions}

Stable carbon and oxygen isotope measurements were performed on all samples collected from the four investigated travertine occurrences and the results are shown in Table 2 . The measured isotope compositions vary within wide ranges: the $\delta^{13} \mathrm{C}$ values range between $-5.9 \%$ and $+2.0 \%$ (V-PDB), while the $\delta^{18} \mathrm{O}$ values vary between $+16.2 \%$ and $+22.0 \%$ ( $\mathrm{V}$-SMOW). The analyses of the recent carbonate precipitation at the ôsforrás spring yielded $\delta^{13} \mathrm{C}$ and $\delta^{18} \mathrm{O}$ values $(1.5 \%$ and $15.3 \%$, respectively) similar to those of the "travertine beard" of the Rudas spring $\left(\delta^{13} \mathrm{C}: 1.4 \%\right.$, $\delta^{18} \mathrm{O}: 15.3 \%$ ) determined by Veres (2007) Table 1).

Table 2

Stable carbon and oxygen isotopic composition of travertine deposits of Gellért Hill

\begin{tabular}{|c|c|c|c|c|}
\hline \multirow{2}{*}{ Name } & \multirow{2}{*}{$\begin{array}{c}\text { Sample } \\
\text { number }\end{array}$} & $\boldsymbol{\delta}^{18} \mathbf{O}$ & $\delta^{18} \mathbf{O}$ & $\delta^{13} \mathbf{C}$ \\
\cline { 3 - 5 } & 1 & -14.3 & 16.2 & 1.9 \\
\hline Gellért Hill, Ifjúsági park & 2 & -12.4 & 18.1 & 2.0 \\
\hline & 3 & -10.0 & 20.6 & 0.2 \\
\hline & 4 & -12.1 & 18.5 & 1.9 \\
\hline & 5 & -12.9 & 17.6 & 1.9 \\
\hline Gellért Hill, Számadó u. & 1 & -10.9 & 19.7 & 0.2 \\
\hline & 2 & -9.2 & 21.4 & 1.7 \\
\hline & 3 & -11.0 & 19.6 & -0.2 \\
\hline & 4 & -11.7 & 18.9 & 0.3 \\
\hline Gellért Hill, Kelenhegyi u. & 1 & -11.0 & 19.5 & 0.2 \\
\hline & 2 & -9.9 & 20.7 & -3.1 \\
\hline & 3 & -8.7 & 22.0 & -5.9 \\
\hline & 1 & -11.3 & 19.3 & -0.5 \\
\hline Gellért Hill, Somlói u. & 1 & -15.1 & 15.3 & 1.5 \\
\hline Gellért Hill, Õsforrás & $1 \mathrm{~b}$ & -14.7 & 15.8 & 1.0 \\
\hline & & & &
\end{tabular}




\section{Discussion}

Paleoenvironmental reconstruction of the Gellert Hill travertine

Paleoenvironmental reconstruction of the travertine located in the Gellért Hill area have already been performed by many authors in the last decades, under better sampling conditions. Most of the travertine was quarried in the 19th century. Papp (1942), Schréter (1953), Scheuer and Schweitzer (1974, 1980, 1988), studied the Gellért Hill travertine in detail and Szöőr et al. (1992) performed some sporadic stable isotope analyses, but no detailed microfacies study, geochemical analyses or radiometric dating on these deposits have been performed yet. Scheuer and Schweitzer (1974) described five travertine occurrences on Gellért Hill facing Német Valley. In this chapter, previously published formation models and our new results are compared, which sometimes support, but in some cases modify the earlier results.

Remnants of travertine spring cones are common in the Buda Hills (e.g. Törökvész lejtő, Szemlő Hill; Kele 2009; Kele et al., submitted) and this observation is true for the Gellért Hill area as well. The travertine deposits of Gellért Hill are small and belong mainly to spring cone type deposits, due to the fact that during their deposition the absence of any morphological depression hindered the formation of lake depositional environments. This could be due to the assumption that the Gellért Hill area was never flooded by the Danube; thus, the river was not able to form depressions for lakes fed by thermal springs.

The travertine of Ifjúsági Park (220-215 m asl, Fig. 5A) was described as a Pliocene warm-water lake deposit by Papp (1942), and Scheuer and Schweitzer (1988) also suggested a lacustrine depositional environment. Previous papers by Scheuer and Schweitzer (1988), Szöőr et al. (1992) and Scheuer et al. (1993) suggested a Lower Pleistocene age for the travertine based on the bear fossil Ursus deningeri described by Dénes Jánossy at the Felszabadulási monument. However, based on our new U/Th age data the travertine of Ifjúsági Park is much younger (250 $\pm 44 \mathrm{ky})$, suggesting Middle Pleistocene spring activity in the Gellért Hill area, where the sedimentological characteristics of the occurrence indicate a spring cone or fissure ridge depositional environment.

The $4-5 \mathrm{~m}$ high and $5 \mathrm{~m}$ wide travertine block located in the garden of Számadó u. 7 sz. (195 m asl; Fig. 5C, D) was previously described as Lower Pleistocene tetarata-type travertine; however, based on its cone-like morphology it is presumably a preserved center of a travertine spring cone. Remnants of plants can also occur in this compact, well-layered but sometimes homogeneous deposit, but its lacustrine origin can be excluded based on its small size and morphology. The presence of oncoids in thin sections (Fig. 8B) could indicate both the presence of bacterial activity and agitated water. Radiometric U/Th analyses of this travertine again yielded Middle Pleistocene ages (180 $\pm 49 \mathrm{ky}$ and $160 \pm 50 \mathrm{ky})$, which are younger than those of the travertine of Ifjúsági Park 


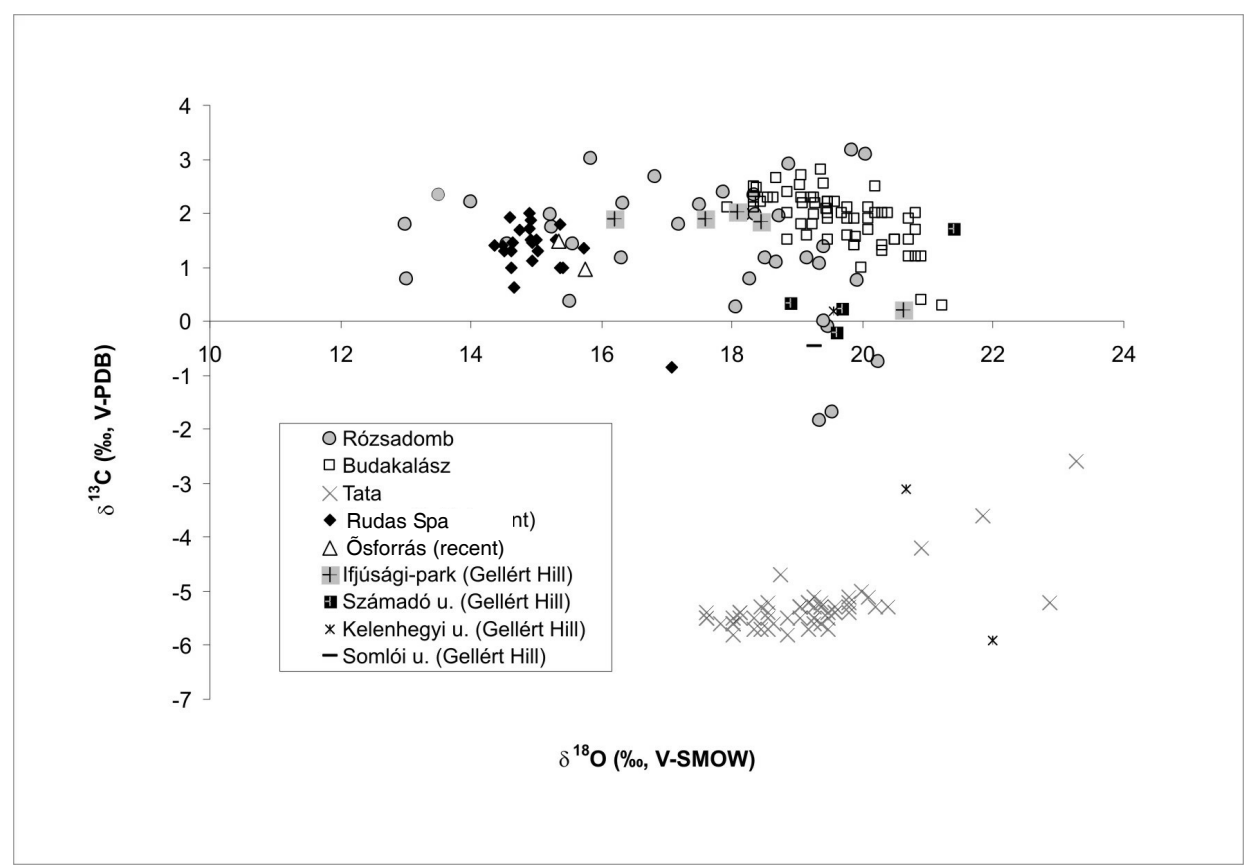

Fig. 9

Comparison of the stable isotopic values of travertine of Gellért Hill, the Upper Pleistocene travertine of Tata, Porhanyó Quarry (Western Gerecse; Kele et al. 2006), the Pleistocene Budakalász travertine (Buda Hills; Kele et al. 2003), the Pleistocene travertine of the Rózsadomb (Kele et al., submitted) and the Holocene carbonate precipitation of Rudas Spa (Budapest; Veres 2007)

situated at higher altitude, that would be of an older age according to Scheuer and Schweitzer (1988).

The travertine deposits of Kelenhegyi u. (170 m asl) and Somlói u. in their current preservation are not suitable for paleoenvironmental reconstruction, due to their weak exposure. However, the plant remnants in the travertine of the Kelenhegyi u. infer shallow water, while the massive, pore-free travertine of Somlói u. (150 m asl, Fig. 7D) points to an open lake environment. The latter occurrence was mentioned by Schréter (1953) and described by Scheuer and Schweitzer (1988) as a tetarata-type limestone.

\section{Discussion of stable isotope data}

\section{Origin of $\mathrm{CO}_{2}$}

The interpretation of the $\delta^{13} \mathrm{C}_{\text {travertine }}$ requires special care, since the $\mathrm{CO}_{2}$ may derive from various sources, like decarbonation of limestone, mantle degassing, hydrolysis and oxidation of reduced carbon, etc. (Pentecost 2005); isotope fractionation processes during and after travertine deposition can also mask the 
source composition. Thus, in order to get more reliable paleoclimatological and paleoenvironmental data from travertine, a better understanding of the processes governing their precipitation and geochemical composition - including stable isotopes - is needed.

Comparing the previously published stable isotope data from the Gerecse and Buda Hills (Kele et al. 2003, 2006; Veres 2007; Kele 2009; Sierralta et al. 2010; Kele et al., submitted) and the new stable isotope data from the Gellért Hill travertine, significant differences can be observed in both the $\delta^{13} \mathrm{C}$ and $\delta^{18} \mathrm{O}$ values between the localities (Fig. 9). The $\delta^{13} \mathrm{C}$ values of travertine of the Buda Hills (Budakalász, Rózsadomb, etc.) range mostly between $+1 \%$ ond $+3 \%$, while the $\delta^{13} \mathrm{C}$ values of that collected from the Gerecse Hills are generally lower in average $(-7 \%$ < $\delta^{13} \mathrm{C}<0 \%$ ) (Kele et al. 2006; Kele, 2009). Among the Pleistocene travertine deposits of Gellért Hill, only that of Ifjúsági-park shows $\delta^{13} \mathrm{C}$ values around $+2 \%$, while the other three occurrences show significantly lower $\delta^{13} \mathrm{C}$ values (Table 2). Especially the travertine detritus of the Kelenhegyi u. show negative $\delta^{13} \mathrm{C}$ values, probably due to the presence of plant debris (represented by remnants in the phytohermal structure) and possible contribution of the isotopically light organic $\mathrm{CO}_{2}$ derived from plant matter decay (Fig. 7C, Fig. 9).

The stable $\mathrm{C}$ isotope compositions of travertine can indicate thermal, magmatic and metamorphic processes; however, the isotope data should be accompanied by detailed geologic knowledge of the area, involving sedimentological and tectonic features. The $\delta^{13} \mathrm{C}$ value of travertine is controlled by the relative amounts and carbon isotope compositions of dissolved inorganic carbon components derived from limestone dissolution during water migration and from $\mathrm{CO}_{2}$ dissolution from different sources (air, oxidation of organic matter, thermometamorphic reactions, etc.).

The analyses of the recent carbonate precipitation at the Gellért Hill Ôsforrás spring resulted in $\delta^{13} \mathrm{C}$ and $\delta^{18} \mathrm{O}$ values similar to those of measured from the "travertine beard" of the Rudas spring by Veres (2007) (Table 1). Besides, the $\delta^{13} \mathrm{C}$ values of recent carbonates are similar to the average values measured so far on the Pleistocene travertine of the Buda Hills. Thus, the origin of the dissolved carbonate (the recharge area and the underground flowpath) and the origin of $\mathrm{CO}_{2}$ have not changed significantly since the Pleistocene. Many former studies have already dealt with the origin of $\mathrm{CO}_{2}$ (e.g. Turi 1986; Minissale 2004) and with the geochemical classification of travertine (Pentecost and Viles 1994; Kele et al. 2003; Pentecost 2005; Kele et al. 2008). In the Buda Hills the measured

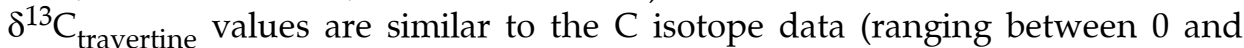
$+3 \%$ ) measured on the primary (marine) carbonates of the Transdanubian Range (Hungary) (Fig. 11 in Haas and Demény 2002).

Paleotemperature calculations

The $\delta^{18} \mathrm{O}$ values of travertine are controlled by many parameters, among which the most important are temperature and $\delta^{18} \mathrm{O}$ value of the travertine- 
depositing thermal water. These parameters are in close relation with climate; however, the effect of diagenesis on the $\delta^{18} \mathrm{O}_{\text {travertine }}$ values cannot be neglected during the interpretation of the stable isotopic data. For warm and wet climatic periods, relatively high $\delta^{18} \mathrm{O}$ values are characteristic, while during colder periods the situation is reversed, which shows the importance of the isotopic composition of water. The $\delta^{18} \mathrm{O}_{\text {travertine }}$ value is also controlled by the temperature of the parent water. In the case of stable isotopic equilibrium and assuming constant $\delta^{18} \mathrm{O}_{\text {water }}$ it can be stated that the higher the temperature of the travertine-depositing thermal water, the lower the $\delta^{18} \mathrm{O}_{\text {travertine }}$ value, and vice versa. In the case of calcite-water oxygen isotopic equilibrium the temperature of formation (i.e. the paleotemperature) can be calculated using the equation of O'Neil et al. (1969), which was modified by Friedman and O'Neil (1977):

$$
10^{3} \ln \alpha=\left(2.78 \times 10^{6}\right) / \mathrm{T}^{2}-2.89
$$

where: $\alpha=\left(\delta^{18} \mathrm{O}_{\text {carbonate }}+10^{3}\right) /\left(\delta^{18} \mathrm{O}_{\text {water }}+10^{3}\right)$

Thus, in the case of isotopic equilibrium the $\delta^{18} \mathrm{O}_{\text {travertine }}$ value is determined by the temperature of the travertine-depositing thermal water and its $\delta^{18} \mathrm{O}$ value. Consequently, $1^{\circ} \mathrm{C}$ change in temperature equals $0.24 \%$ shift in the $\delta^{18} \mathrm{O}_{\text {travertine }}$ (Craig 1964; Andrews 2006). It is important to note that the travertine was not necessarily deposited under equilibrium conditions (Kele et al. 2008; Kele et al., submitted) and its deposition cannot be precisely described with the above (1) equation.

Stable oxygen isotope analyses of recently forming carbonate and spring water were conducted at two localities of the Gellért Hill area (the Ösforrás spring and the Rudas Spa), while the $\delta^{18} \mathrm{O}_{\text {water }}$ values and temperature data were also available from the literature. Thus, it was possible to examine the relationship between the $\Delta$ calcite-water values of the recent calcite precipitations and the theoretical values calculated using the equation of Friedman and O'Neil (1977). For the calculations the $\delta^{18} \mathrm{O}_{\text {water }}$, data of Babidorics et al. (1998) and Fórizs (unpublished, measured in 2008) were used, while the $\delta^{18} \mathrm{O}_{\text {travertine }}$ values of the Rudas Spa were taken from Veres (2007). It must be mentioned that the $\delta^{18} \mathrm{O}_{\text {water }}$ values of the Rudas Spa show no significant change between 1998 and now, so they can be used for calculations. Figure 10 shows that the measured $\Delta$ calcitewater values show the same positive shift as was observed in the case of the recently forming Egerszalók travertine (Kele et al. 2008).

According to Babidorics et al. (1998) the waters infiltrated during the Ice Age (more than $10 \mathrm{ky}$ ago) are characterized with $\delta^{18} \mathrm{O}$ values between $-14 \%$ and $-11 \%$, while the Holocene waters generally have $\delta^{18} \mathrm{O}$ values between $-9.3 \%$ o and $10 \%$. The mean $\delta^{18} \mathrm{O}$ values of the Gellért Hill travertine occurrences range between 17.6 and 20.7 (\%o, V-SMOW) (Table 1), while when considering all samples the $\delta^{18} \mathrm{O}$ values vary between 16.2 and 22 (\%o, V-SMOW) (Table 2). 


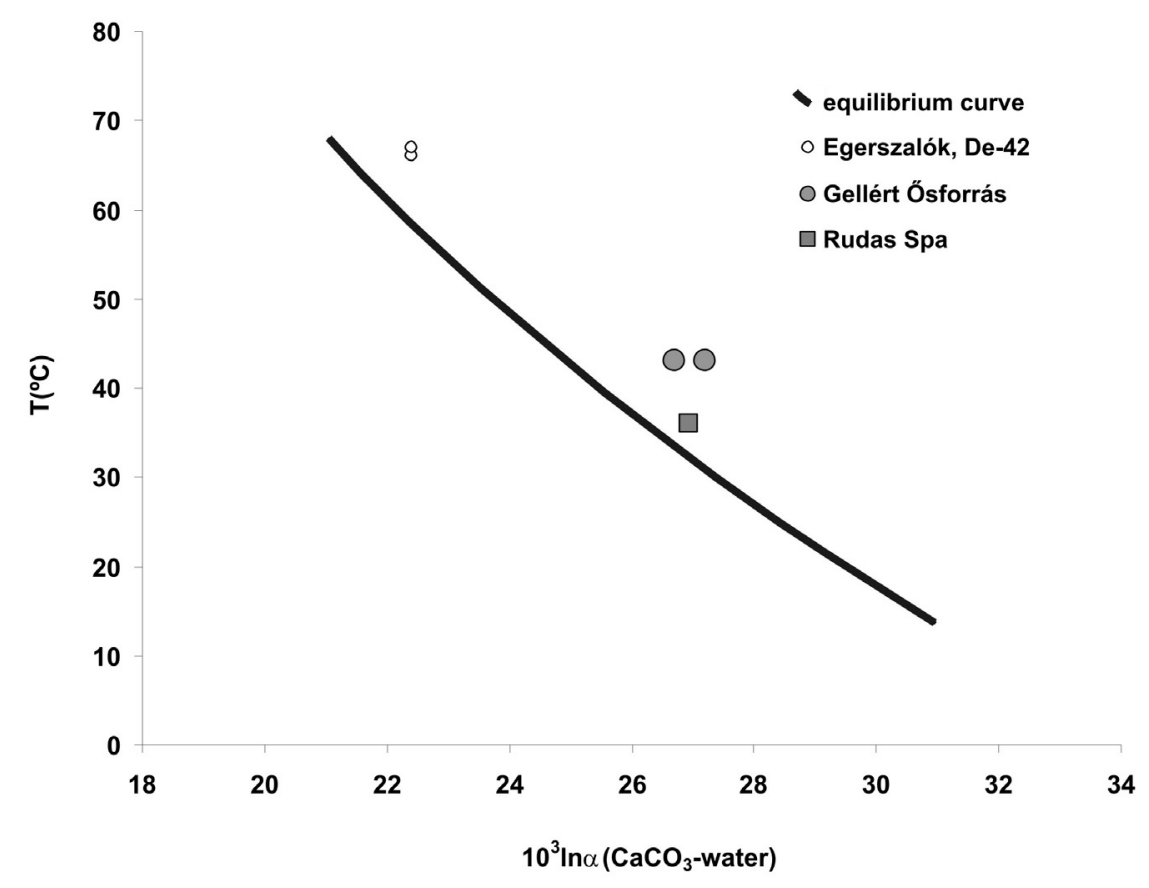

Fig. 10

Fractionation of oxygen isotopes between calcite and water vs. the measured temperature. Beside the recent carbonate precipitations of Gellért Hill, Ösforrás and Rudas Spa, the values of the recent Egerszalók travertine (Kele et al. 2008) are also shown. Equilibrium values were calculated based on the equation of Friedman and $\mathrm{O}^{\prime} \mathrm{Neil}(1977)$ in the $10-70^{\circ} \mathrm{C}$ temperature range

Pleistocene climate changes could have influenced both the temperature and the oxygen isotope composition of the thermal springs; thus, both their temperature and $\mathrm{O}$ isotope composition could have been different from those of today. Since our U/Th measurements on the Gellért Hill travertine deposits yielded Upper Pleistocene ages between 160 and $250 \mathrm{ky}$, Holocene water infiltration can be excluded. However, during the Pleistocene warm periods could have occurred with $\delta^{18} \mathrm{O}$ values slightly lower than those of the Holocene waters. Assuming that the water of the paleo-springs of Gellért Hill derived from precipitation infiltrated during interstadial periods of the Pleistocene, then their $\delta^{18} \mathrm{O}$ value could be around $-12 \%$ ( $( \pm 1 \%$ ) ; thus, the calculated paleo-temperatures (using the equation of Friedman and O'Neil 1977) could range between $14( \pm 4)^{\circ} \mathrm{C}$ and $41( \pm 6){ }^{\circ} \mathrm{C}$. Since Kele et al. (2008) demonstrated that the use of the "equilibrium" equation of Friedman and O'Neil (1977) underestimates the real deposition temperature by about $8^{\circ} \mathrm{C}$ (and the same phenomenon was observed at Gellért Hill as discussed above), then we can conclude that the temperature of the travertine-depositing paleo-springs of Gellért Hill could have been between 22 $( \pm 4){ }^{\circ} \mathrm{C}$ and $49( \pm 6){ }^{\circ} \mathrm{C}$. 
Based on the available stable isotope data and microfacies descriptions, relative differences in paleo-temperatures can be calculated between the occurrences. Since there are differences between the $\delta^{18} \mathrm{O}$ values of the Gellért Hill travertine occurrences, it cannot be excluded that the temperature of their parent thermal springs was different. However, diagenesis can affect the $\delta^{18} \mathrm{O}_{\text {travertine values, }}$ causing differences in the oxygen isotopic compositions due to the presence of secondary carbonates. Among the deposits of Gellért Hill the Ifjúsági Park and the Számadó u. spring cone type travertine could have been deposited from the highest temperature water, since they have the lowest $\delta^{18} \mathrm{O}_{\text {travertine }}$ values, while from the lowest temperature water the travertine of the Kelenhegyi $u$. was deposited. In the latter the remnants of plants also indicate moderate temperature conditions and a possible lacustrine depositional environment.

\section{Uplift rates: spatial and temporal variations}

The majority of the age data of Hungarian travertine presented in preceding papers are based mainly on paleomagnetic measurements (Latham and Schwarcz 1990; Lantos 2004), paleontological remnants (i.e. Jánossy 1979) and geomorphological considerations; only sporadic radiometric (U/Th) dating analyses have been performed (e.g. Kretzoi and Pécsi 1982). Our U/Th data are the first from the Gellert Hill travertine and they are important in the reconstruction of the past structural development of the Buda Hills. The Pleistocene uplift history of the Buda Hills has attracted special attention in recent years. For the calculations of uplift rates Leél-Ôssy (1997), Leél-Ốssy and Surányi (2003) and Szanyi et al. (2009) used U/Th data from cave deposits, while Ruszkiczay-Rüdiger et al. (2005) summarized the previously published (paleontological, paleomagnetic, U/Th and ${ }^{14} \mathrm{C}$ ) age data and used them for the calculations. According to Burbank and Anderson (2001) the incision/uplift rate can be calculated based on the following equation:

$$
\text { (1) } \quad \text { i (rate) }=[\text { elevation }(\mathrm{mm})-\text { elevation of Danube asl }(\mathrm{mm})] \text { / age }(\mathrm{yr})
$$

When calculating uplift rates it must be assumed that travertine deposition took place on or close to the elevation of the Danube River, which is the general erosion level of the area. U/Th ages measured from terrace-cover travertine show only the minimum age of the covered surface. Besides, the individual travertine occurrences are characterized only with a single U/Th measurement, although the deposition of the entire travertine mass of a given occurrence often took some hundred thousand years (e.g. Sierralta et al. 2010). If the youngest sample of the occurrence is used for the calculation of the uplift rate, then the maximal uplift rate will be calculated, while using the oldest sample of the occurrence the calculated uplift rate can decrease significantly. For terrace dating lacustrine travertine is the most appropriate type of deposit, since slope and tetarata-type 
travertine usually form from springs located above the erosion level; thus, they cannot be used for precise dating. The calculated uplift rates are affected by the error of the U/Th measurements (in this study this is $\pm 50 \mathrm{ky}$ ) caused by the Th contamination of travertine; thus, we determined the minimal and maximal uplift rates in the case of both studied occurrences. The calculated uplift rate in $\mathrm{mm} / \mathrm{yr}$ is only an average value which obscures the nature of the tectonic processes and can be regarded as reliable if the uplift of the area and the incision of the river was continuous. It is more likely (and the presence of terraces supports this hypothesis) that the uplift rate was higher than the calculated values and the uplift process was periodic.

Using radiometric age data of the carbonate precipitations of the József Hill cave, Leél-Ôssy (1997) determined 0.15-0.3 mm/yr, while Ruszkiczay-Rüdiger et al. (2005) calculated a $0.23 \mathrm{~mm} / \mathrm{yr}$ average uplift rate for the Buda Hills. Based on literature data from the cover deposits of the terraces, Ruszkiczay-Rüdiger et al. (2005) concluded that the incision (uplift) history of the Danube River in the Gerecse and Buda Hills can be divided into two periods characterized with different uplift rates: between 9 my and $360 \mathrm{ky}, 0.02$ and $0.04 \mathrm{~mm} / \mathrm{yr}$, while in the last $360 \mathrm{ky}$ of the Pleistocene, 0.16 and $0.18 \mathrm{~mm} / \mathrm{yr}$. However, the conclusions of Ruszkiczay-Rüdiger et al. (2005) were only rough estimates due to the scarcity of precise age data. Since at the time of earlier age determination studies (e.g. Latham and Schwarcz 1990) the upper age limit of the U/Th dating technique was only $360 \mathrm{ky}$, the uplift rate calculations from deposits older than $360 \mathrm{ky}$ become quite uncertain, as was emphasized by Ruszkiczay-Rüdiger et al. (2005). The other problem is that the starting date of the incision (uplift) and its change with time is not known. Szanyi et al. (2009) dated calcite sheets from the Pál-völgyi cave and for the time period of 500-280 ky they calculated a $0.06-0.3 \mathrm{~mm} / \mathrm{yr}$ uplift rate, whereas using the data published by Leél-Ôssy (1997) and the samples located below $155 \mathrm{~m}$ asl in the Pál-völgyi cave for the 280-70 ky interval, they determined $0.16 \mathrm{~mm} / \mathrm{yr}$ (i.e. accelerating) uplift.

Kele (2009) published a series of new U/Th data from the travertine of the Buda Hills, which play an important role in the reconstruction of the Pleistocene development of the Danube Valley. The steep morphology of Gellért Hill can itself be regarded as evidence of high uplift rate. Uplift rates calculated from travertine deposited at different elevations at Ifjúsági Park ( $220 \mathrm{~m}$ asl, $250 \pm 44 \mathrm{ky})$ and Számadó u. (195 m asl, $180 \pm 49 \mathrm{ky})$ resulted in rates of $0.47 \mathrm{~mm} / \mathrm{yr}(0.40-0.57$ $\mathrm{mm} / \mathrm{yr})$ and $0.52 \mathrm{~mm} / \mathrm{yr}(0.41-0.71 \mathrm{~mm} / \mathrm{yr})$, respectively, which are higher than the results of earlier calculations. Besides, calculations using the U/Th data measured on the travertine of the Rózsadomb (i.e. Barsi u., Bimbó u., Szőlészeti Kutatóintézet, Apostol u.) resulted in incision/uplift rates between 0.20-0.25 $\mathrm{mm} / \mathrm{yr}$ (Kele et al., submitted). The data indicate that the area of Gellért Hill was uplifted about two times faster than the Rózsadomb, which implies selective uplift for the area of the Buda Hills during the Pleistocene, as was suggested (but not proved) by Wein (1977). 
If the uplift rate is calculated from the age and elevation data of the two localities studied here, then a value of $0.35 \mathrm{~mm} / \mathrm{yr}$ is obtained, meaning that the rate was significantly higher than $0.5 \mathrm{~mm} / \mathrm{yr}$ in the last $160 \mathrm{ky}$, as is also shown by the data for the Számadó u. locality. These calculations are based on the general assumption that travertine is formed at the bank of River Danube, i.e. at the erosion base. If the studied travertine had formed at higher elevations, then the calculated uplift rate would be lower. Formation of the younger travertine occurrence at about $10 \mathrm{~m}$ higher than the erosion base would yield an uplift rate about $0.25 \mathrm{~mm} / \mathrm{yr}$. Our data suggest that either the uplift rate changed in space and time, or the spring discharge locations migrated.

\section{Conclusions}

In this paper we present detailed sedimentological and geochemical investigations performed on the Gellért Hill travertine. Based on textural observations and oxygen isotope compositions the travertine of Ifjúsági Park and Számadó $u$. are spring cone deposits and formed from higher temperature thermal water than the travertine of Kelenhegyi u., which could have been deposited in a shallow water environment. Measured calcite-water oxygen isotope fractionations in the case of recent carbonate precipitations of the Gellért Hill, Sárosfürdő and Rudas Spas show that the calcite was precipitated under non-equilibrium conditions. Assuming that the water of the paleo-springs of Gellért Hill derived from precipitation infiltrated during interstadial periods of the Pleistocene, and considering non-equilibrium deposition (i.e. using the empirical calcite-water oxygen isotope fractionation of Kele et al. 2008), the calculated paleotemperature could range between $22( \pm 4)^{\circ} \mathrm{C}$ and $49( \pm 6){ }^{\circ} \mathrm{C}$. Our new U/Th data proved that the area of Gellért Hill was characterized by thermal spring activity during the Middle Pleistocene ( 160-260 ky ago), contrary to previously published theories. From the elevation level and radiometric age of the Ifjúsági Park $(250 \pm 44 \mathrm{ky}, 220 \mathrm{~m}$ asl $)$ and Számadó u. travertine deposits $(180 \pm 49 \mathrm{ky}, 195 \mathrm{~m}$ asl) a relative decrease of the paleokarst water-level can be reconstructed. The uplift rates calculated from the U/Th age data and elevation of travertine occurrences ranges between $0.47-0.52 \mathrm{~mm} / \mathrm{yr}$ in the area of Gellért Hill and differ significantly from the rates calculated for the Rózsadomb area $(0.20-0.25 \mathrm{~mm} / \mathrm{yr}$; Kele et al., submitted), suggesting selective uplift of the different blocks of the Buda Hills during the Middle Pleistocene.

\section{Acknowledgements}

The U/Th dating analyses were supported by the Hungarian Academy of Sciences and the National Science Council providing a travel grant for Sándor Kele to the laboratory of the National Taiwan University (Taipei, Taiwan). The 
paper benefited from the comments of the two reviewers: Gergely Surányi and Szabolcs Leél-Őssy. Special thanks are due to Szabolcs Leél-Őssy and Anita Erôss, who allowed us to visit the springs of Gellért Hill.

\section{References}

Alföldi, L., L. Béltelky, T. Böcker, J. Horváth, K. Korim, P. Liebe, R. Rémi (Eds) 1968: Budapest hévízei (Thermal waters of Budapest). - VITUKI Kiadvány, 365 p. (In Hungarian.)

Andrews, J.E. 2006: Paleoclimatic records from stable isotopes in riverine tufas: Synthesis and review. - Earth-Science Reviews, 75, pp. 85-104.

Babidorics, J., I. Fórizs, S. Papp 1998: Isotope hydrogeological study of the thermal karst system in the Buda Mountains, Hungary. - RMZ-Materials and Geoenvironment, 45/1-2, pp. 8-12.

Bakacsi, Zs. 1993: A süttői édesvízi mészkő szedimentológiai vizsgálata (Sedimentological study of the freshwater limestone of Süttő). - MSc thesis, Eötvös University, Budapest, 108 p. (In Hungarian.)

Burbank, D.W., R.S. Anderson 2001: Tectonic Geomorphology. - Blackwell Science, USA, pp. 22-26.

Craig, H. 1964: The isotopic geochemistry of water and carbon in geothermal area. - Symp. Nuclear Geol. Geothermal Areas, Spoleto, Italy, pp. 17-53.

Deák, J. 1978: Environmental isotopes and water chemical studies for groundwater research in Hungary. - In: Isotope Hydrology 1978, v. I., IAEA-SM-228/13, IAEA, Vienna, 1979, pp. 221-249.

Deák, J., T.B. Coplen 1996: Identification of Holocene and Pleistocene groundwaters in Hungary using oxygen and hydrogen isotopic ratios. - In: Isotope in Water Resources Management, v. 1: Vienna, International Atomic Energy Agency, 438 p.

Dunham, R.J. 1962: Classification of carbonate rocks according to depositional texture. - In: Ham, W.E. (Ed.): Classification of Carbonate Rocks. Mem. Am. Ass. Petrol. Geol., 1 pp. 108-121. Tulsa, Oklahoma.

Edwards, R.L., J.H. Chen, T.-L. Ku, G.J. Wasserburg 1987: Precise timing of the last interglacial period from mass spectrometric analysis of Th-230 in corals. - Science, 236, pp. 175-192.

Edwards, R.L., F.W. Taylor, G.J. Wasserburg 1988: Dating earthquakes with high-precision thorium230 ages of very young corals. - Earth and Planetary Science Letters, 90, pp. 371-381.

Erôss, A., J. Mádl-Szónyi, A. Mindszenty, I. Müller 2006: Conclusions from a negative tracer test in the urban thermal karst area, Budapest, Hungary. - In: Tellam, J.H. (Eds): Urban Groundwater Management and Sustainability, Springer, pp. 289-298.

Erôss, A., J. Mádl-Szőnyi, A.É. Csoma 2008: Discharge features of the Buda Thermal Karst System, Budapest, Hungary. - In: Mádl-Szőnyi, J. (Ed.): From the artesian paradigm to basin hydraulics: The contribution of József Tóth to Hungarian Hydrogeology, Publishing Company of Budapest University of Technology and economics, pp. 91-102.

Fekete, J. 2006: A radon eredetének vizsgálata a Gellért-hegy Rákóczi-forráscsoportján (On the origin of radon at the Rákóczi Spring-group of Gellért Hill). - MSc. thesis, Eötvös University, 79 p. (In Hungarian.)

Folk, R.L. 1959: Practical petrographic classification of limestones. - Bull. Am. Ass. Petrol. Geol., 43, pp. 1-38.

Ford, T.H., H.M. Pedley 1996: A review of tufa and travertine deposits of the world. - Earth-Science Reviews, 41, pp. 117-175.

Fórizs, I., J. Deák, Gy. Tóth, Á. Lorberer 2007: Origin of groundwater in the Budapest thermal karst regime by preliminary environmental isotope data. - Studia Universitatis Babes-Bolyai, 52/1, pp. 92-93.

Földvári, M., Zs. Berner, D. Stüben 2003: Thermoanalytical study of Quaternary thermal lacustrine travertine occurrences in Hungary (Buda-Vár-hegy, Budakalász, Szomód-Les-hegy). - Acta Geologica Hungarica, 46, pp. 195-204. 
Friedman, I., J.R. O'Neil 1977: Compilation of stable isotope fractionation factors of geochemical interest. - In: Data of Geochemistry 6th, Geol. Surv. Prof. Paper 440-KK, p. 61

Haas, J., A. Demény 2002: Early dolomitisation of Late Triassic platform carbonates in the Transdanubian Range (Hungary). - Sedimentary Geology, 151, pp. 225-242.

Hajnal, G., B. Kleb, P. Görög, Á. Török 2005: A Rác fürdő térségének mérnökgeológiai és hidrogeológiai értékelése (Engineering geological and hydrogeological evaluation of the Rác Spa area). - Hidrológiai Közlöny, 85/5, pp. 63-67. (In Hungarian.)

Hennig, G.J., R. Grün, K. Brunnacker, M. Pécsi 1983: $\mathrm{Th}^{230} / \mathrm{U}^{234}$ sowie ESR Alterbestimmungen einiger Travertine in Ungarn. - Eiszeitalter and Gegenwart, 33, pp. 7-19.

Horusitzky, H. 1939: Budapest Duna jobbparti részének hidrogeológiája (Hydrogeology of the right side of the Danube River). - Hidrológiai Közlöny, 18, pp. 1-404. (In Hungarian.)

Jánossy, D. 1979: A magyarországi pleisztocén tagolása gerinces faunák alapján (Stratigraphy of the Pleistocene in Hungary, based on Vertebrate fauna). - Akadémiai Kiadó. Budapest, 207 p. (In Hungarian.)

Kele, S. 2009: Édesvízi mészkövek vizsgálata a Kárpát-medencéből: paleoklimatológiai és szedimentológiai elemzések (Investigations on freshwater limestones from the Carpathianbasin: paleoclimatological and sedimentological studies). - PhD dissertation, Eötvös Loránd Tudományegyetem, 176 p. (In Hungarian.)

Kele, S., O. Vaselli, Cs. Szabó, A. Minissale 2003: Stable isotope geochemistry of Pleistocene travertine from Budakalász (Buda Mts, Hungary). - Acta Geologica Hungarica, 46/2, pp. $161-175$

Kele, S., L. Korpás, A. Demény, P. Kovács-Pálffy, B. Bajnóczi, Zs. Medzihradszky 2006: Paleoenvironmental evaluation of the Tata Travertine Complex (Hungary), based on stable isotopic and petrographic studies. - Acta Geologica Hungarica, 49/1, pp. 1-31.

Kele, S., A. Demény, Z. Siklósy, T. Németh, T. Mária, M.B. Kovács 2008: Chemical and stable isotope compositions of recent hot-water travertines and associated thermal waters, from Egerszalók, Hungary: depositional facies and non-equilibrium fractionations. - Sedimentary Geology, 211, pp. 53-72.

Kele, S., Gy. Scheuer, A. Demény, C.-C. Shen, C. Hong-Wei 2010: A Rózsadomb (Budapest) édesvízi mészköveinek U/Th sorozatos kormeghatározása és stabilizotóp-geokémiai vizsgálata (Uranium-series dating and geochemical study of the travertines located on the Rózsadomb Hill (Budapest). - Földtani Közlöny (in press, accepted manuscript). (In Hungarian.)

Kormos, T., Z. Schréter 1916: Előzetes jelentés a Budai-hegység és a Gerecse hegység szélein elôforduló édesvízi mészkövek tanulmányozásáról (Preliminary report about the freshwater limestones located on the margin of the Buda and Gerecse Hills) - MÁFI Évi Jel. 1915-ről, pp. 542-544. (In Hungarian.)

Korpás, L., L. Fodor, Á. Magyari, Gy. Dénes, J. Oravecz 2002: A Gellért-hegy földtana, karszt- és szerkezetfejlődése (Geology, karst and structural evolution of Gellért Hill). - Karszt és Barlang, 1998-1999/1-2, pp. 57-93. (In Hungarian.)

Korpás, L., P. Kovács-Pálffy, M. Lantos, M. Földvári, L. Kordos, E. Krolopp, D. Stüben, Zs. Berner 2004: A budai Vár-hegy negyedidőszaki termális tavi travertínójának szedimentológiája, geokémiája, kronológiája és paleokarszt fejlődése. Integrált esettanulmány (Sedimentology, geochemistry, chronology and palaeokarst evolution of Quaternary thermal lacustrine travertine. An integrated case study from Vár-hegy, Budapest, Hungary). - Földtani Közlöny, 134/4, pp. 541-562.

Kovács, J., P. Müller 1980: A Budai-hegyek hévizes tevékenységének kialakulása és nyomai (Evolution and evidence of the thermal water activity in the Buda Hills). - Karszt és Barlang, 2, pp. 93-98. (In Hungarian.)

Kretzoi, M., M. Pécsi 1982: Pliocene and Quaternary chronostratigraphy and continental surface development of the Pannonian Basin. - Quaternary Studies in Hungary, INQUA Hungarian, National Committee, pp. 11-42. 
Lantos, M. 2004: Északkelet-dunántúli negyedidôszaki édesvízi mészkőszelvények magnetosztratigráfiai korrelációja (Magnetostratigraphic correlation of Quaternary travertine sequences in NE Transdanubia). - Földtani Közlöny, 134/2, pp. 227-236. (In Hungarian with English abstract.)

Latham, A.G., H.P. Schwarcz 1990: Magnetic polarity of travertine samples from Vértesszőlős. - In: Kretzoi, M., T. Dobosi (Eds): Vértesszőloós site, man and culture. Akadémiai Kiadó, Budapest, pp. 553-555.

Leél-Ôssy, Sz. 1997: A József-hegyi-barlang (Budapest) geológiai viszonyai, fejlődéstörténete és a Rózsadomb környéki termálkarsztos barlangok genetikája (Geology and evolution history of the József Hill cave (Budapest) and genetics of the thermal karstic caves around the Rózsadomb). - Kandidátusi értekezés. 114 p. (In Hungarian.)

Leél-Ôssy, Sz., G. Surányi 2003: Peculiar hydrothermal caves in Budapest, Hungary. - Acta Geologica Hungarica, 46/4, pp. 407-436.

Leél-Ôssy, Cs., Sz. Leél-Őssy, P. Adamkó 2009: A Citadella-kristálybarlang ásványtani-geomorfológiai vizsgálata (Mineralogical and geomorphological study of the Citadella crystal cave). - Karszt és Barlang, 2007/1-2, pp. 67-78.

McCrea, J.M. 1950: On the isotopic chemistry of carbonates and a paleotemperature scale. - Journal of Chemical Physics, 18, pp. 849-857.

Mihályi-Lányi, I. 1964: Sedimentpetrograpische Untersuchungen. - In: Vértes, L. (Ed.): Tata, eine mittelpaläolithische Travertin-Siedlung in Ungarn. Akadémiai Kiadó, Budapest, pp. 37-42

Minissale, A. 2004: Origin, transport and discharge of $\mathrm{CO}_{2}$ in central Italy. - Earth-Science Reviews, 66, pp. 89-141.

O'Neil, J.R, R.N. Clayton, T.K. Mayeda 1969: Oxygen isotope fractionation in divalent metal carbonates. - The J. of Chem. Physics, 51, pp. 5547-5558.

Opauszky, L., L. Matus, J. Lukács, I. Kiss 1964: Die Bestimmung der Paleotemperatur durch Messung des ${ }^{18} \mathrm{O} /{ }^{16} \mathrm{O}$ Isotopverhältnisses von Karbonaten. - In: Vértes, L. (Ed.): Tata, eine mittelpaläolithische Travertin-Siedlung in Ungarn. Akadémiai Kiadó, Budapest, pp. 19-29.

Palotai, M., J. Mádl-Szőnyi, Á. Horváth 2005: A Budapest Gellért- és a József-hegy felszín alatti vizeiben mért radon- és rádiumtartalom lehetséges forrásai (Potential radon and radium sources for subsurface water of Gellért and József Hills, Budapest, Hungary). - Általános Földtani Szemle, 29, pp. 25-40. (In Hungarian.)

Papp, F. 1942: Budapest meleg gyógyforrásai (Warm thermal springs of Budapest). - A Budapesti Központi Gyógy- és Üdülőhelyi Bizottság kiadványa, 252 p. (In Hungarian.)

Papp, F. 1962: A budapesti langyos és meleg források földtani múltja (Geological history of the lukewarm and thermal springs of Budapest). - Hidrológiai Tájékoztató. 2, pp. 18-20. (In Hungarian.)

Pentecost, A. 1995: The Quaternary travertine deposits of Europe and Asia. - Quaternary Science Review, 14, pp. 1005-1028.

Pentecost, A. 2005: Travertine. - Springer-Verlag, 445 p.

Pentecost, A., H. Viles 1994: A review and reassessment of travertine classification. - Géographie physique et Quaternarie, 48, pp. 305-314.

Pécsi, M. 1959: A magyarországi Duna-völgy kialakulása és felszínalaktana (Formation and geomorphology of the Danube valley in Hungary). - Földrajzi Monográfiák, III, Akadémiai Kiadó, Budapest, 346 p. (In Hungarian.)

Pécsi, M. 1973: A vértesszôllôsi ópaleolit ôsember telephelyének geomorfológiai helyzete és abszolút kora (Geomorphological position and absolute age of the lower paleolithic site at Vértesszőllós, Hungary). - Földrajzi Közlemények, 21, pp. 109-125. (In Hungarian.)

Richards, D.A., J.A. Dorale 2003: U-series chronology of speleothems and paleoclimate. UraniumSeries Geochemistry. - Reviews in Mineralogy and Geochemistry, 52, pp. 407-460

Rózsavölgyi, J. 1964: Die mineralogische Untersuchung der Bohrkerne. - In: Vértes. L. (Ed.): Tata, eine mittelpaläolithische Travertin-Siedlung in Ungarn. Akadémiai Kiadó, Budapest, pp. 31-36. 
Ruszkiczay-Rüdiger, Zs., L. Fodor, G. Bada, Sz. Leél-Össy, E. Horváth, TJ. Dunai 2005: Quantification of Quaternary vertical movements in the central Pannonian Basin: A review of chronologic data along the Danube River, Hungary. - Tectonophysics, 410, pp. 157-172.

Schafarzik, F. 1921: Visszapillantás a budai hévforrások fejlődéstörténetére (The evolution of thermal spring in Buda). - Hidrológiai Közlöny, 1. pp. 9-14. (In Hungarian.)

Scheuer, Gy. 1964: A budapesti hévizek vízföldtana (Hydrogeology of the thermal waters of Budapest). - Doctoral dissertation. (In Hungarian.)

Scheuer, Gy., F. Schweitzer 1974: Új szempontok a Budai-hegység környéki édesvízi mészkóösszletek képzódéséhez (New aspects for the formation of travertines in the Buda Hills). - Földrajzi Közlemények, 22/2, pp. 113-134. (In Hungarian.)

Scheuer, Gy., F. Schweitzer 1980a: A budai hévízforrások fejlődéstörténete a felsôpannontól napjainkig (Development history of the thermal springs of Buda from the Upper-Pannonian until nowadays). - Hidrológiai Közlöny, 11, pp. 492-501. (In Hungarian.)

Scheuer, Gy., F. Schweitzer 1980b: A budai termális karsztforrások fejlődéstörténete a felsôpannontól a holocénig (Development history of the karstic thermal springs of Buda from the UpperPannonian until the Holocene). - Hidrológiai Közlöny, 60/12, pp. 223-244. (In Hungarian.)

Scheuer, Gy., F. Schweitzer 1988: A Gerecse és a Budai-hegység édesvízi mészkőösszletei (Freshwater limestones of the Gerecse and Buda Hills). - Földrajzi Tanulmányok, 20, Akadémiai Kiadó, Budapest, 131 p. (In Hungarian.)

Scheuer, Gy., F. Schweitzer 1989: Genetics and occurrence of Holocene travertines in Hungary. Geomorphological and Geoecological Essays, Studies in Geography in Hungary, 25, Akadémiai Kiadó, Budapest, pp. 39-47.

Scheuer, Gy., Gy. Szöőrr, P. Sümegi, É. Balázs, E. Hertelendi, F. Schweitzer. 1993: A magyarországi quarter és neogén édesvízi mészkövek termoanalitikai és izotógeokémiai elemzése fácies és rétegtani értékeléssel (Thermoanalytical and isotope-geochemical study of Quaternary and Neogene travertines in Hungary with facies and stratigraphical evaluation). - Hidrológiai Közlöny, 73/5, pp. 298-306. (In Hungarian.)

Schréter, Z. 1919: Harmadkori és pleisztocén hévforrások tevékenységének nyomai a Budaihegységben (Traces of Tertiary and Pleistocene thermal spring activity in the Buda Hills). MAFI Évkönyve, 19 (5), pp. 179-231. (In Hungarian.)

Schréter, Z. 1953: A Budai- és Gerecse-hegység peremi édesvizi mészkő előfordulásai (Travertine deposits along the border of the Buda and Gerecse Hills). - Földtani Intézet Évi Jelentése 1949rôl, pp. 111-150. (In Hungarian.)

Schwarcz, H.P. 1980: Absolute age determination of archeological sites by uranium series dating of travertines. - Archaeometry, 22, pp. 3-24.

Schwarcz, H.P., I. Skoflek 1982: New dates for the Tata, Hungary archaeological site. - Nature, 295, pp. 590-591.

Schwarcz, H.P., A.G. Latham 1984: Uranium series age determination of travertines from the site of Vértesszőlős, Hungary. - J. Archaeol. Sci., 11, pp. 327-336.

Schwarcz, H.P., A.G. Latham 1989: Dirty calcites: 1. uranium series dating of contaminated calcite using leachates alone. - Chemical Geology (Isotope Geoscience Letters) 80/1, pp. 35-43.

Shen, C.-C., R.L. Edwards, H. Cheng, J.A. Dorale, R.B. Thomas, S.B. Moran, S.E. Weinstein, H.N. Edmonds 2002: Uranium and thorium isotopic and concentration measurements by magnetic sector inductively coupled plasma mass spectrometry. - Chemical Geology, 185, pp. 165-178.

Shen, C.-C., H. Cheng, R.L. Edwards, S.B. Moran, H.N. Edmonds, J.A. Hoff, R.B. Thomas 2003" Measurement of attogram quantities of ${ }_{231} \mathrm{~Pa}$ in dissolved and particulate fractions of seawater by isotope dilution thermal ionization mass spectroscopy. - Analytical chemistry, 75, pp. 1075-1079.

Shen, C.-C., H-T. Lin, M-F. Chu, E-F. Yu, X. Wang, J.A. Dorale 2006: Measurements of natural uranium concentration and isotopic composition with permil-level precision by inductively coupled plasma-quadrupole mass spectrometry. - Geohemistry, Geophysics, Geosystems, 7/9, doi:10.1029/2006GC001303. 
Shen, C.-C. et al. 2008: Variation of initial 230Th/232Th and limits of high precision U-Th dating of shallow-water corals. - Geochimica et Cosmochimica Acta, 72, pp. 4201-4223.

Shieh, Y.N., H.P. Jr. Taylor 1969: Oxygen and carbon isotope studies of contact metamorphism of carbonate rocks. - Journal of. Petrology, 10, pp. 307-331.

Sierralta, M., S. Kele, F. Melcher, U. Hambach, J. Reinders, R. van Geldern, M. Frechen 2010: Characterisation and Uranium-series dating of Travertine from Süttő in Hungary. - Quaternary International, 222, 1-2, pp. 178-193.

Spötl, C., T.W. Vennemann 2003: Continuous-flow isotope ratio mass spectrometric analysis of carbonate minerals. - Rapid communications in mass spectrometry, 17, pp. 1004-1006.

Szanyi, Gy., G. Bada, G. Surányi, Sz. Leél-Őssy, Zs. Varga 2009: A Budai-hegység pleisztocén kiemelkedéstörténete barlangi lemezes kalcitkiválások uránsoros kormeghatározása alapján (Pleistocene uplift history of the Buda Hills (Hungary) using uranium-series dating of cave rafts). - Földtani Közlöny, 139/4, pp. 353-366. (In Hungarian.)

Szöőr, Gy., É. Balázs, P. Sümeghy, Gy. Scheuer, F. Schweitzer, E. Hertelendi 1992: Thermoanalytical and isotope-geochemical study of the travertines in Hungary with facies and stratigraphical evaluation. - In: Szöőr, Gy. (Ed.): Research studies on facies, palaeobiogeochemistry and palaeoecology, Debrecen, pp. 93-107. (In Hungarian.)

Turi, B. 1986: Stable isotope geochemistry of travertines. - In: Fritz, P., J.Ch. Fontes (Eds): Handbook of Environmental Isotopic Geochemistry. - Elsevier Science Publishers, Amsterdam, pp. 207-238.

Vendel, M., P. Kisházy 1964: Összefüggések melegforrások és karsztvizek között a DunántúliKözéphegységben megfigyelt viszonyok alapján (Relation between karstwaters and thermal springs based on observed conditions in the Transdanubian Central Range). - MTA Múszaki Tudományok Osztálya Közleményei, 32, pp. 393-417, 33, pp. 205-234. (In Hungarian.)

Veres, V. 2007: A Rudas-fürdő travertínója (Travertine of the Rudas Spa). - MSc thesis, Eötvös University, Budapest, 116 p. (In Hungarian.)

Vígh, Gy., H. Horusitzky. 1940: Karszthidrológiai és hegységszerkezeti megfigyelések a Budaihegységben (Karst hydrological and structural observations in the Buda Hills). - MÁFI Évi Jel. 1933-35 évről, 4. pp. 1413-1440.

Weed, W.H. 1889: Formation of travertine and siliceous sinter by the vegetation of hot springs. - U.S. Geol. Surv. Annual Rep., 9, pp. 613-676.

Wein, Gy. 1977: A Budai-hegység tektonikája (Tectonics of the Buda Hills). - MÁFI Alkalmi kiadvány, 76 p. Budapest (In Hungarian.) 